\title{
Inflation Targeting and the Pass-through Effect in Mongolia
}

\author{
Hiroyuki Taguchi (correspondence author) \\ Dept. of Japanese and Asian Studies, Saitama University \\ 255 Shimo-Okubo, Sakura-ku, Saitama, Japan \\ Tel: 81-48-858-3324 E-mail: tagusaya0710@s3.wh.qit.ne.jp \\ Jambaldorj Bolortuya \\ Dept. of Japanese and Asian Studies, Saitama University, Japan \\ 255 Shimo-Okubo, Sakura-ku, Saitama, Japan \\ E-mail: bolo_422@yahoo.com
}

$\begin{array}{lcc}\text { Received: March 28, } 2019 & \text { Accepted: April 12, } 2019 \quad \text { Published: April 26, } 2019 \\ \text { doi:10.5296/ber.v9i2.14579 } & \text { URL: https://doi.org/10.5296/ber.v9i2.14579 }\end{array}$

\begin{abstract}
This paper aims to provide empirical evidence on the relationship between inflation targeting and the pass-through effect from exchange rate to consumer prices, focusing on the case of Mongolia. The study estimates a vector-autoregressive model, and examines the impulse responses of consumer prices to the shock of exchange rate for the pre-inflation targeting period and the post-inflation targeting period. The empirical analysis identified the existence of the pass-through effect during the pre-inflation targeting period and the loss of the pass-through during the post-inflation targeting period. It was speculated that the loss of the pass-through comes from the "forward-looking" monetary policy rule in Mongolian inflation targeting, so that it can work on the expectations of domestic agents such that they are less inclined to change prices in response to a given exchange rate shock.
\end{abstract}

Keywords: Inflation targeting, Pass-through effect, Mongolia, Vector Autoregressive model, Forward-looking rule

\section{Introduction}

The Mongolian economic system shifted from a centrally planned economy to a market-based economy in early 1990s, and a great number of political and economic reforms 
have been undertaken since then. Under the market-based regime, Mongolian economy has achieved 6.3 percent economic growth on the average in terms of real GDP for the period from 1993 to 2017. ${ }^{1}$ Through the growth process, Mongolia has graded up its economic status from "low income" to "middle income" since 2007, according to the World Bank Classifications. ${ }^{2}$

While attaining the rapid economic growth, on the other hand, Mongolian economy has often suffered from serious inflation. During the transition period from 1991 to 1994, for instance, the rate of annual increase in consumer prices reached 60-400 percent, and even after the transition period, its rate has often recorded double-digit percentage in economic-booming times. ${ }^{3}$ To cope with the frequent hike of inflation rate, the Bank of Mongolia (BOM) together with the Government of Mongolia have ever made several efforts to stabilize inflation. One of the noteworthy policy-changes is the introduction of "inflation targeting". The BOM has adopted the inflation targeting since 2007, which contains the policy mandate of announcing the mid-term targeted inflation rate to the public and of taking every possible measures to maintain inflation rate within its targeted range.

Regarding the assessment of the inflation targeting, there seems to be a consensus in academic literature and policy discussions that inflation targeting has so far been successful to stabilize inflation in advanced economies in the history of its operation since the 1990s (e.g. Mishkin and Posen, 1998; Mishkin and Schmidt-Hebbel, 2007). As far as emerging market economies including Mongolia are concerned, however, there has been rather less evidence to support the performance of inflation targeting due to the relatively shorter history of its operation and due to some difficulties in its management.

The difficulties that emerging market economies have faced in operating their inflation targeting might come from exchange rate fluctuation. In small, open economies including Mongolia, in particular, exchange rate fluctuation itself has large influence on domestic prices through the "pass-through" effect. The existence of the pass-through effect, as Eichengreen (2002) argued, makes it difficult for monetary authorities to control inflation and to perform inflation targeting well. There is, however, a counterargument against the pass-through effect on inflation targeting. Gagnon and Ihrig (2004) argued that an inflation targeting framework reduces the pass-through effect, in the sense that domestic agents are less inclined to change prices in response to a given exchange rate shock under the strong commitment of a monetary authority to price stability.

This paper aims to place the aforementioned discussion of the relationship between the inflation targeting and the pass-through effect into the context of empirical analyses, focusing

\footnotetext{
${ }^{1}$ The data of real GDP is retrieved by "US Dollars at constant prices (2010) in millions" from UNCTAD STAT: http://unctadstat.unctad.org/EN/.

${ }^{2}$ See the website: https://datahelpdesk.worldbank.org/knowledgebase/articles/906519.

${ }^{3}$ The description on consumer prices is based on the database of International Financial Statistics of International Monetary Fund: https://www.imf.org/en/data.
} 
on the case of Mongolia. To be specific, this study provides empirical evidence on a decline in the pass-through effect in accordance with the adoption of the inflation targeting in 2007 in Mongolia, by applying a vector-autoregressive (VAR) estimation. The Mongolian economy could be an appropriate example to examine the pass-through effect, since it is a typical small, open economy. Its economic size is 11.1 billion US dollars at current prices in terms of GDP in 2017, while the average size of Asian developing economies is 583.0 billion US dollars in the same year. The Mongolian ratio of "imports of goods and services" to GDP is 55.3 percent on the average during the period from 1995 to 2017 after transforming into a market-based economy, while the average ratio in Asian developing economies is 35.3 percent during the same period. ${ }^{4}$

The rest of the paper is structured as follows. Section 2 reviews the literature related to the debate of pass-through effects and clarifies this study's contributions. Section 3 conducts the empirical analysis of the pass-through effect in relation with the inflation targeting in Mongolia through a VAR estimation. Finally Section 4 summarizes and concludes.

\section{Literature Review and Contributions}

This section reviews the literature related to the discussion of pass-through effects and clarifies this study's contributions.

The theoretical literature on exchange rate pass-through has focused mainly on the issue of why the pass-through to import and consumer prices is incomplete. As one of the most prominent articles, Dornbusch (1987) describes incomplete pass-through as firms' behaviors that operate in imperfect market structures that adjust their mark-up in response to an exchange rate shock. Most of the empirical literature has also supported the existence of incomplete pass-through. Lee (1997), for instance, shows the evidence that domestic market concentration systematically affects the imperfect pass-through of individual industries in Korea. The empirical studies have also found the evidence of the large differences in pass-through effects across countries, and investigated the underlying factors for the differences. Among them, Taylor (2000) argues that the decline in pass-through is due to the low inflation environment that has recently been achieved in many countries, and presents the evidence that low inflation itself has caused the low pass-through. ${ }^{5}$

Regarding the literature on the relationship between the pass-through and inflation targeting, there seems to be confronting arguments, as was stated in the introduction. First of all, Gagnon and Ihrig (2004) emphasizes the role of inflation targeting as one of the determinants of pass-through. They develop a simple theoretical model to explain how monetary policy influences inflation expectations and pass-through at the macroeconomic level. The model implies that anti-inflationary actions and credibility of the monetary authorities are important factors behind the reduced pass-through of exchange rate changes into consumer prices.

\footnotetext{
${ }^{4}$ The data of the GDP and the ratio of "imports of goods and services" to GDP are retrieved respectively from UNCTAD STAT: http://unctadstat.unctad.org/EN/.
}

${ }^{5}$ Regarding the recent progress in the studies of exchange-rate-determination mechanism, see Guo (2017). 
Based on this model, they examine the monetary and inflation experiences of a sample of 20 industrial countries between 1971 and 2003, and find the followings. First, countries with low and stable inflation rates tended to have low rates of pass-through from exchange rates to consumer prices. Second, countries in which either the level or the standard deviation of inflation fell tended to have large declines in the rate of pass-through. Third, the rate of pass-through tended to decline the most in countries where monetary policy shifted strongly towards stabilizing inflation, in particular, to the adoption of inflation targeting. Finally, they suggest that the inflation targeting framework may reduce the pass-through, in the sense that domestic agents are less inclined to change prices in response to a given exchange rate shock under the strong commitment of the monetary authority toward price stability.

There is, however, a counterargument to Gagnon and Ihrig (2004), namely, the one emphasizing the difficulties in controlling inflation due to the pass-through effect in small, open emerging market economies. The aforementioned study by Eichengreen (2002) argues that: changes in import prices due to movements in the exchange rate are passed through to domestic prices faster in emerging market economies than in industrial economies; a history of inflation may have raised agents' awareness of, and sensitivity to, imported inflation and have led to formal indexation; because the commitment to price stability may lack credibility, the transitory shocks leading to depreciation of the exchange rate may be validated by policy and, hence, become permanent; and thus the high pass-through effect also makes inflation forecasting more difficult.

The majority of subsequent studies supports the argument of Gagnon and Ihrig (2004) by providing the evidence of the decline in pass-through effect by the adoption of inflation targeting such as: Coulibaly and Kempf (2010) with the samples of 27 emerging market economies (15 inflation targeters and 12 inflation non-targeters), Dilla et al. (2017) with 19 countries (8 high income countries and 11 middle income countries), Edward (2006) with 7 countries (Australia, Brazil, Canada, Chile, Israel, Korea and Mexico), Daboussi and Thameur (2014) with 6 emerging markets in Latin America and Asia (Thailand, Philippines, Peru, Mexico, Indonesia and Brazil), Siregar and Goo (2008) with Indonesia and Thailand, Odria et al (2012) with Peru, Guillermo and Brindis (2014) with Mexico, Oladipo (2017) with South Africa, and Karahan (2017) with Turkey. Some studies, however, identify the unchanged or lasting pass-through effects even after adopting inflation targeting such as: Nogueira (2007) with 8 countries (Canada, United Kingdom, Sweden, Czech Republic, South Korea, Mexico, Brazil, and South Africa), Kuncoro (2015) with Indonesia, and Dube (2016) with South Africa.

The difference in the pass-through effects under inflation targeting, namely, whether the pass-through declines or remains unchanged, might be explained by several reasons. One of the reasons is described by Taguchi and Sohn (2014) as follows: the pass-through effects depends on the modality of inflation targeting; the inflation targeting of Korea with an inflation-responsive rule in a forward-looking form leads to the loss of pass-through effect, whereas the one of Thailand with an inflation-responsive rule in a backward-looking manner and the one of the Philippines with no inflation-responsive rule produce no clear changes in pass-through effects; the forward-looking inflation targeting could reduce the pass-through 
effect, since it effectively works on the expectations of domestic agents towards targeted inflation.

This study contributes to the literature reviewed above, by enriching the evidence on Mongolia with a small, open emerging market economy, which has adopted inflation targeting since 2007. There is one study, Buyandelger (2015), which estimates the exchange rate pass-through into import price and inflation by $0.69 \%$ and $0.49 \%$ respectively in short run. The study, however, does not deal with the linkage between pass-through and inflation targeting explicitly. Thus the contribution could be significant in the sense that the pass-through effect is examined for the first time in the context of inflation targeting adopted in Mongolia.

\section{Empirical Analysis}

This section conducts the empirical analysis of the pass-through effect in relation with the inflation targeting in Mongolia. To be specific, the analysis aims to provide the evidence on a decline in the pass-through effect in accordance with the adoption of the inflation targeting in 2007 in Mongolia, by applying a VAR estimation. The section starts with clarifying key variables, data and methodology for a VAR estimation, and then discusses the estimation outcomes.

\subsection{Key Variables and Data}

At the beginning, the study identifies the following two variables for analyzing the pass-through effect by using a VAR estimation in Mongolia: exchange rate (exr) and consumer prices (cpi). The data for the two variables are retrieved from International Financial Statistics (IFS) of International Monetary Fund. The consumer prices are taken from the series of "Consumer Price Index" with 2010=100. The exchange rate, expressed as the "Domestic Currency per U.S. Dollar, Period Average", is processed into the index with $2010=100$. Thus one unit of each variable is approximately equal to one percentage point. The sample data are quarterly ones, covering the period from the fourth quarter of 1991 to the third quarter of 2018, based on the IFS data constraint. Figure 1 displays the trends in the consumer prices and exchange rate by their year-on-year rate. By rough observation, the two variables appears to synchronize before the adoption of inflation targeting in 2007 rather than after its adoption in Mongolia. Their correlation should, however, be statistically tested by a more precise manner through the VAR estimation later on.

Before conducting the VAR model estimation, the study investigates the stationary property of each variable's data by employing a unit root test, and if needed, a co-integration test for a set of variables' data. The unit root test is conducted on the null hypothesis that a level and/or a first difference of the individual data have a unit root. In case that the unit root test tells us that each variable's data are not stationary in the level, but stationary in the first-difference, a set of variables' data corresponds to the case of $I(1)$, and then can be further examined by a co-integration test for the "level" data. If a set of variables' data are identified to have a co-integration, the use of the "level" data is justified for a VAR model estimation. 


\section{$\triangle 1$ Macrothink}

Business and Economic Research

ISSN 2162-4860

2019, Vol. 9, No. 2

For a unit root test, the study adopts the Ng-Perron unit root test ${ }^{6}$ on the null hypothesis that each variable has a unit root. This test constructs four test statistics: modified forms of Phillips and Perron (1988) statistics (MZa, MZt), the Bhargava (1986) statistic (MSB), and the Point Optimal statistic (MPT). For a co-integration test, the study employs the Johansen test (see Johansen, 1995). The both tests are conducted by including "trend and intercept" in the test equation.

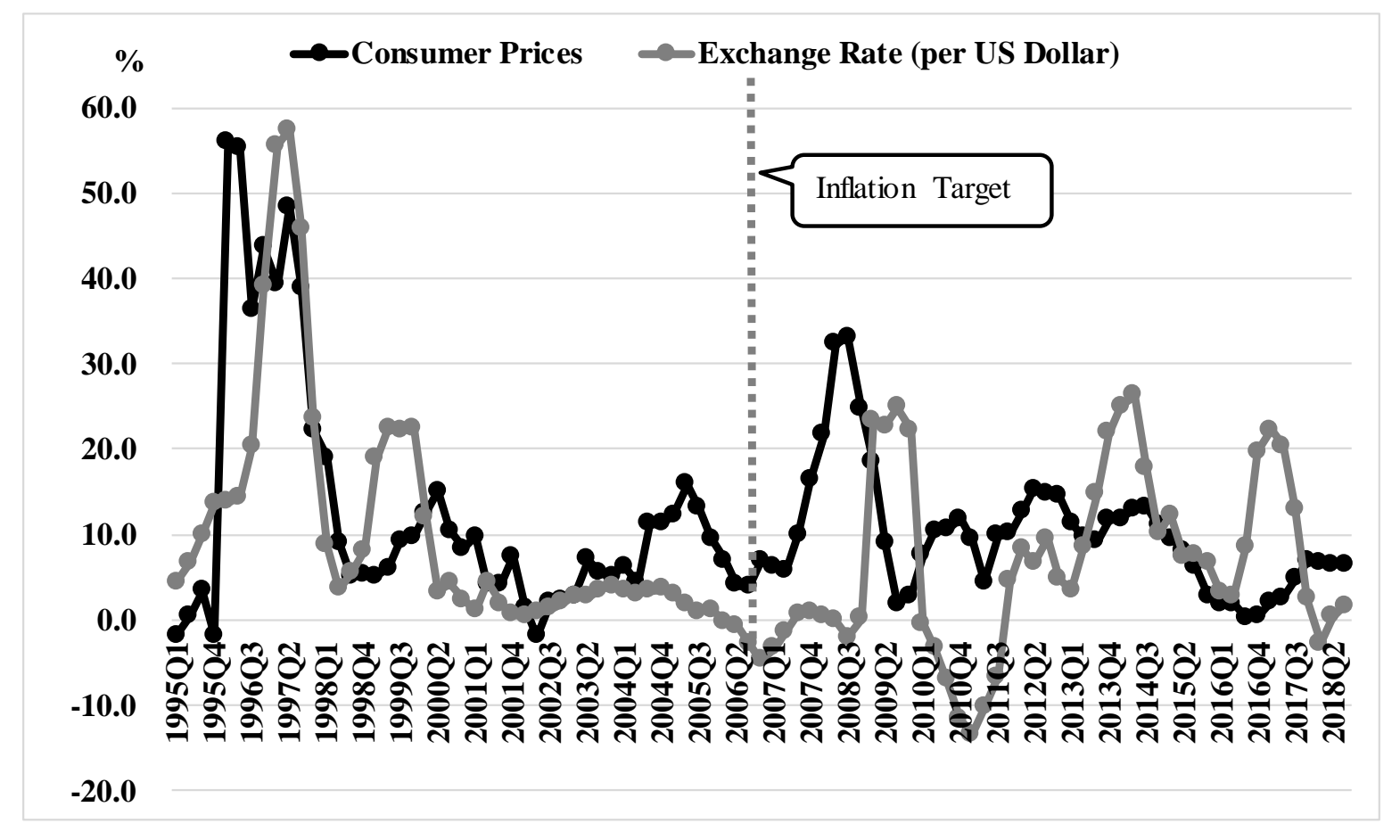

Figure 1. Consumer Prices and Exchange Rate (year-on-year rate)

Source: International Financial Statistics (IFS)

Table 1 reports the result of both unit root and co-integration tests. For the data of two variables, the unit root test identified a unit root in their levels, but rejected it in their first differences at the conventional level of significance, thereby the variables following the case of $I(1)$. The co-integration test was, thus, conducted further on the combination of variables for examining the pass-through effect, and both the Trace test and the Maximum-eigenvalue test implied that the level series of a set of variables' data were co-integrated. We thus utilize the level data for a VAR model estimation.

\subsection{Methodology}

This subsection clarifies the methodology in the analysis of the pass-through effects. This study uses a VAR model, basically following Zorzi et al. (2007). As Zorzi et al. (2007) suggests, the VAR model is useful in the sense that it allow for potential and highly-likely endogeneity between the variables of interest, and also for tracing out the dynamic responses

\footnotetext{
${ }^{6} \mathrm{Ng}$ and Perron (2001) introduced a new unit root test, which used detrended data and a lag selection procedure that improved on previous methods.
} 
of variables to exogenous shocks overtime.

The study, by modifying the specification of Zorzi et al. (2007), specifies a VAR model equation for estimation in the following way:

$$
y_{\mathrm{t}}=\mu+V_{1} y_{\mathrm{t}-1}+V_{2} z_{\mathrm{t}}+\varepsilon_{\mathrm{t}}
$$

where $y_{\mathrm{t}}$ is a column vector of the endogenous variables with year $t$, i.e., $y_{\mathrm{t}}=\left(\operatorname{exr}_{\mathrm{t}} \text { cpi }_{\mathrm{t}}\right)^{\prime} ; \mu$ is a constant vector; $V_{1}$ and $V_{2}$ is a coefficient matrix; $y_{\mathrm{t}-1}$ is a vector of the lagged endogenous variables; $z_{\mathrm{t}}$ is a vector of the control variable of inflation rate (cpig) shown by the annual increasing rate of consumer prices; and $\varepsilon_{\mathrm{t}}$ is a vector of the random error terms in the system.

Table 1. Tests for Unit Root and Co-integration

\begin{tabular}{ccccc}
\hline \hline & \multicolumn{4}{c}{ Ng-Perron Unit Root Test } \\
\cline { 2 - 5 } & MZa & MZt & MSB & MPT \\
\cline { 2 - 5 }$c p i$ & -4.463 & -1.356 & 0.303 & 19.352 \\
exr & -5.721 & -1.617 & 0.282 & 15.792 \\
\hline$d(c p i)$ & $-35.621 * * *$ & $-4.204 * * *$ & $0.118 * * *$ & $2.643 * * *$ \\
$d($ exr $)$ & $-47.637 * * *$ & $-4.871 * * *$ & $0.102 * * *$ & $1.956 * * *$ \\
\hline \hline & \multicolumn{3}{c}{ Johansen Cointegration Test } \\
\cline { 2 - 4 } & \multicolumn{2}{c}{ Trace Statistics } \\
\hline \hline
\end{tabular}

Source: Author's estimation

The model here is specified based on the following considerations. First, the model focuses only on the key variables directly related to our concern, i.e. the pass-through effects in order to preserve the degrees of freedom under the limited time-series of data, whereas Zorzi et al. (2007) included rather comprehensive variables including oil price index, output index and interest rate. Second, the model inserts inflation rate (cpig) as an exogenous variable to control for the factor that can affect the pass-through (i.e., a proxy variable of "persistence of inflation") to reflect the Taylor hypothesis as was mentioned in Section 2. Third, the model includes the lag chosen based on the various information criteria as well as the limited time-series data (one lag is finally adopted in the model).

The VAR model estimation in (1) should have different samples for the periods before the adoption of inflation targeting (pre-inflation targeting) and after that (post-inflation targeting), since the purpose of this study is to investigate whether the adoption of inflation targeting in 2007 would have reduced the pass-through effect in Mongolia. To be specific, the period of pre-inflation targeting is from the fourth quarter of 1991 to the fourth quarter of 2006, and the period of post-inflation targeting is from the first quarter of 2007 to the third quarter of 2018. Since the period for 1991-1994, the transition period from a centrally planned economy to a market-based economy, showed the hyperinflation with 60-400 percent, that period might be excluded from the pre-inflation targeting period, so that the alternative pre-inflation targeting 
period can be from the first quarter of 1995 to the fourth quarter of 2006. The sample division by the first quarter of 2007 at the time of adopting inflation targeting could also be justified statistically by the Chow's breakpoint test to diagnose a breakpoint by the statistics with probabilities for the hypothesis of parameter stability over different periods. Table 2 identifies the existence of a breakpoint in the first quarter of 2007 in both cases with and without the transition period for 1991-1994 in the regression of consumer prices by exchange rate and inflation rate (cpig). Thus the estimations for the different periods are justified by the breakpoint of the first quarter of 2007.

Table 2. Chow Breakpoint Test

\begin{tabular}{lccc}
\hline \hline & Breakpoint & F-statistic & Probability \\
\hline cpi \& exr for 1991Q4-2018Q3 & 2007Q1 & 59.357 & 0.000 \\
cpi \& exr for 1995Q1-2018Q3 & 2007Q1 & 48.747 & 0.000 \\
\hline \hline
\end{tabular}

Source: Author's estimation

Based on the reduced-form VAR model estimation (1), the study examines the impulse responses of consumer prices (cpi) to the shocks of exchange rate (exr) to examine the pass-through effect. In examining the impulse response under the assumption of the contemporaneous interaction between the variables, the structural shock should be identified by imposing some restrictions in the VAR model specification. In general, to identify structural shocks, there are two kinds of approaches to impose the restrictions: short-run restrictions and long-run restrictions. This study employs the Cholesky restriction as one of the short-run restrictions with the following recursive orders: from exchange rate (exr) to consumer prices $(c p i)$ in the first place. Then a sensitive analysis by adopting an alternative ordering from consumer prices (cpi) to exchange rate (exr) should be carried out to confirm the robustness of the model performance. By imposing the Cholesky restriction, the error term of reduced-form equation (1) could be linked with the structural shock of the variable. The estimated results of the positive response of consumer prices (cpi) to the shocks of exchange rate (exr) would imply the existence of pass-through effect from exchange rate to consumer prices.

\subsection{Estimation Outcomes and Interpretation}

Table 3, Table 4 and Figure 2 report the estimated outcomes of the VAR models and the impulse responses, respectively. The main findings are summarized as follows. First, the estimated VAR models show significantly positive coefficients of inflation rate (cpig) in any equations with consumer prices (cpi) being an explained variable. It suggests that the exogenous variable of inflation rate, a proxy variable of "persistence of inflation", would be working well in the models reflecting the Taylor hypothesis that inflation itself is positively correlated with persistence of inflation.

Second, there is a clear contrast in the impulse response of consumer prices (cpi) to the shock of exchange rate (exr): for the period of pre-inflation targeting (both for 1991Q4-2006Q4 and 
for 1995Q1-2006Q4), consumer prices positively respond to the shock of exchange rate at conventionally significant level after three or four quarters, whereas for the post-inflation target period, the response of consumer prices to the exchange rate shock is insignificant. Another contrast is found in the response of exchange rate (exr) to the shock of consumer prices (cpi): for the post-inflation period, exchange rate represents significantly positive response to the consumer prices shock, whereas for the pre-inflation targeting period (both for 1991Q4-2006Q4 and for 1995Q1-2006Q4), the response is not significant. The first contrast implies that the adoption of inflation targeting in 2007 in Mongolia would contribute to a loss of pass-through effect from exchange rate to consumer prices. The second contrast suggests that the inflation, representing an economic risk that has been rising recently under high mobility of foreign capitals, would directly lead to currency depreciation.

Third, a sensitive analysis confirms the robustness of the estimation results. The lower box in Table 4 indicates the result of the impulse response under the alternative recursive order from consumer prices (cpi) to exchange rate (exr). The result also reveals a clear contrast in the responses: the positive response of consumer prices to exchange rate shock (after one quarter) for the pre-inflation targeting, and insignificant response for the post-inflation targeting period. It thus implies the existence of pass-through before the adoption of inflation targeting and its loss after the inflation targeting.

Table 3. VAR Model Estimation

\begin{tabular}{|c|c|c|c|c|c|c|}
\hline & \multicolumn{4}{|c|}{ Pre Inflation Target } & \multirow{2}{*}{\multicolumn{2}{|c|}{$\frac{\text { Post Inflation Target }}{\text { 2007Q1-2018Q3 }}$}} \\
\hline & \multicolumn{2}{|c|}{ 1991Q4-2006Q4 } & \multicolumn{2}{|c|}{ 1995Q1-2006Q4 } & & \\
\hline & exr & cpi & exr & cpi & exr & cpi \\
\hline \multirow{2}{*}{$e x r_{-1}$} & $1.003 * * *$ & $0.081 *$ & $1.006 * * *$ & $0.111 * *$ & $0.906 * * *$ & 0.026 \\
\hline & {$[19.285]$} & [1.949] & [22.697] & {$[2.486]$} & {$[16.547]$} & {$[1.060]$} \\
\hline \multirow{2}{*}{$c p i_{-1}$} & -0.037 & $0.874 * * *$ & -0.064 & $0.854 * * *$ & $0.097 * *$ & $0.987 * * *$ \\
\hline & {$[-0.489]$} & [14.042] & {$[-0.996]$} & [12.987] & [2.172] & [48.158] \\
\hline \multirow{2}{*}{ const. } & 2.056 & 0.023 & $2.794 * *$ & -1.969 & 1.449 & -0.893 \\
\hline & [1.537] & {$[0.021]$} & [2.123] & {$[-1.481]$} & {$[0.352]$} & {$[-0.476]$} \\
\hline \multirow{2}{*}{ cpig } & $0.011 * *$ & 0.006 & $0.035^{*}$ & $0.060 * * *$ & -0.042 & $0.190 * * *$ \\
\hline & [2.170] & [1.476] & [1.729] & [2.937] & {$[-0.346]$} & [3.420] \\
\hline $\operatorname{Adj} . R^{2}$ & 0.991 & 0.987 & 0.990 & 0.979 & 0.978 & 0.996 \\
\hline
\end{tabular}

Note: $* * *, * *, *$ denote rejection of null hypothesis at the $99 \%, 95 \%$ and $90 \%$ level of significance, respectively. The figure in [ ] are t-value.

Source: Author's estimation 
[Pre Inflation Target: 1991Q4-2006Q4]

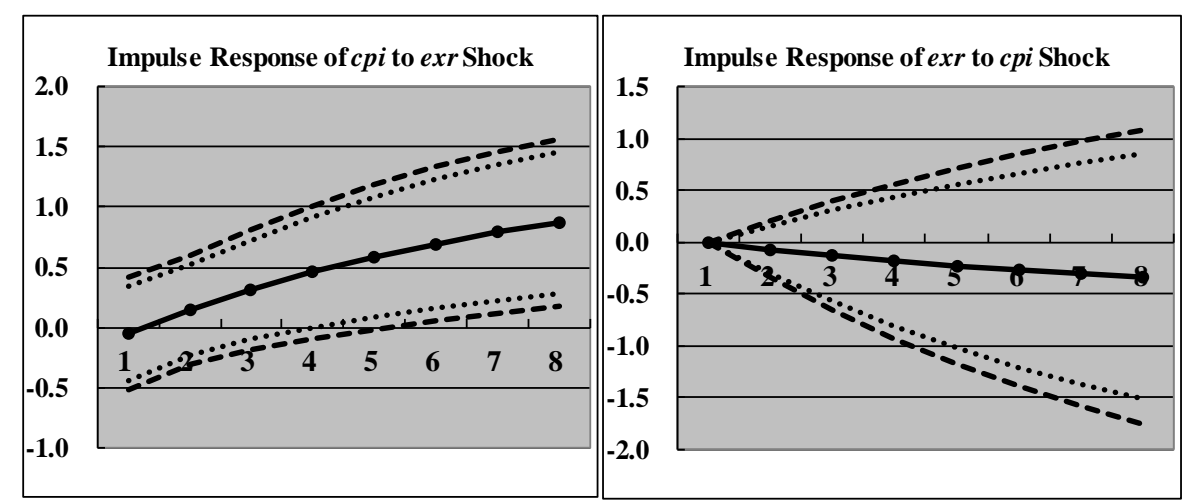

[Pre Inflation Target: 1995Q1-2006Q4]
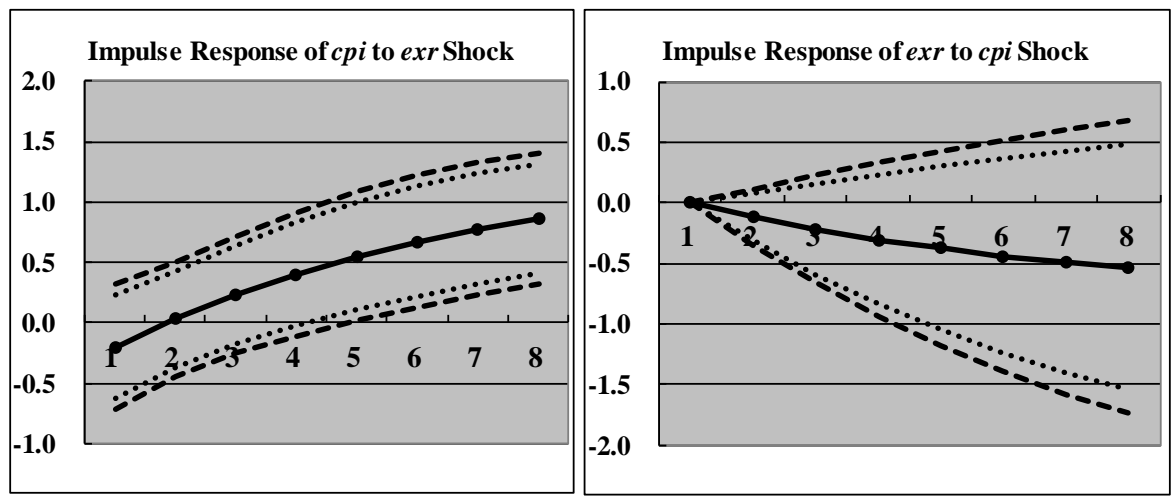

[Post Inflation Target: 2007Q1-2018Q3]
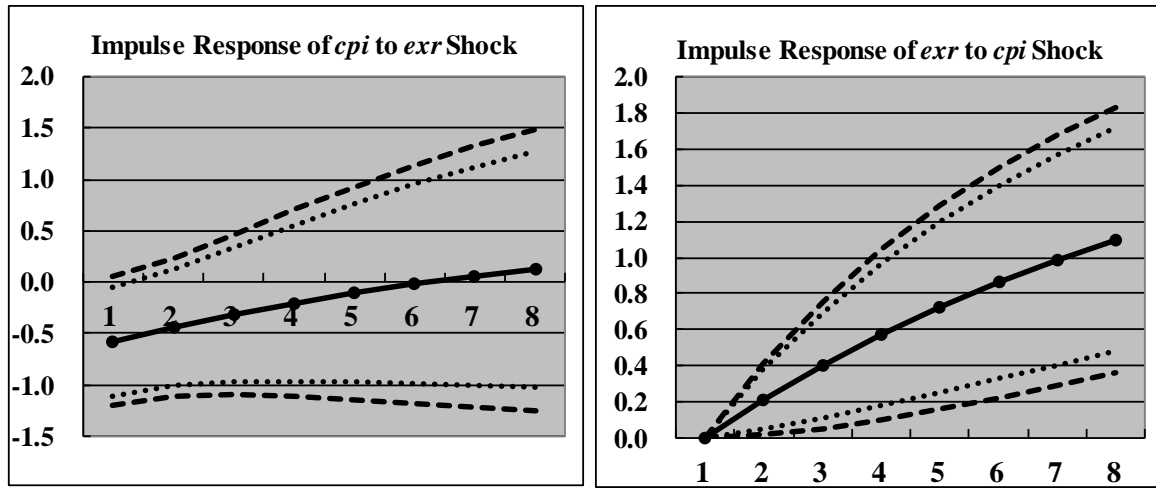

Figure 2. Impulse Responses

Note: The fine and coarse dotted lines denote a 90 and 95 percent error band over 8-quarter horizons.

Source: Author's estimation 
Table 4. Impulse Responses of Consumer Prices (cpi) to Exchange Rate Shock (exr)

\begin{tabular}{|c|c|c|c|}
\hline & \multicolumn{2}{|c|}{ Pre Inflation Target } & \multirow{2}{*}{$\frac{\text { Post Inflation Targe }}{\text { 2007Q1-2018Q3 }}$} \\
\hline & 1991Q4-2006Q4 & 1995Q1-2006Q4 & \\
\hline \multicolumn{4}{|c|}{ Recursive Order from exr to cpi (in \%) } \\
\hline 1st Quarter & -0.04 & -0.20 & -0.57 \\
\hline 2nd Quarter & 0.14 & 0.03 & -0.43 \\
\hline 3rd Quarter & 0.31 & 0.23 & -0.31 \\
\hline 4th Quarter & $0.45 *$ & 0.40 & -0.20 \\
\hline 5th Quarter & $0.58 *$ & $0.55 * *$ & -0.10 \\
\hline 6th Quarter & $0.69 * *$ & $0.67 * *$ & -0.02 \\
\hline 7th Quarter & $0.78 * *$ & $0.77 * *$ & 0.05 \\
\hline 8th Quarter & $0.87 * *$ & $0.86 * *$ & 0.12 \\
\hline \multicolumn{4}{|c|}{ Recursive Order from cpi to exr (in \%) } \\
\hline 1st Quarter & 0.00 & 0.00 & 0.00 \\
\hline 2nd Quarter & $0.18 * *$ & $0.20 * *$ & 0.12 \\
\hline 3rd Quarter & $0.34 * *$ & $0.37 * *$ & 0.23 \\
\hline 4th Quarter & $0.48 * *$ & $0.52 * *$ & 0.34 \\
\hline 5th Quarter & $0.60 * *$ & $0.64 * *$ & 0.43 \\
\hline 6th Quarter & $0.71 * *$ & $0.74 * *$ & 0.51 \\
\hline 7th Quarter & $0.80 * *$ & $0.83 * *$ & 0.58 \\
\hline 8th Quarter & $0.88 * *$ & $0.90 * *$ & 0.65 \\
\hline
\end{tabular}

Note: $* *, *$ denote rejection of null hypothesis at the $95 \%$ and $90 \%$ level of significance.

Source: Author's estimation

Focusing on the pass-through effect, the interpretation for the loss of pass-through under the inflation targeting in Mongolia should be further discussed, since the reviewed literature in the section 2 represents the mixed outcomes of pass-through effects affected by inflation targeting. As Taguchi and Sohn (2014) argues, one of the differences on whether the pass-through declines or remains unchanged after adopting inflation targeting would come from the modality of inflation targeting: the loss of pass-through effect requires the inflation 
targeting accompanied with an inflation-responsive rule in a "forward-looking" manner. Taguchi and Khishigjargal (2018), for the first time, examines the monetary policy rule under inflation targeting in Mongolia, and finds that the Mongolian current monetary policy rule under inflation targeting is characterized as inflation-responsive rule with "forward-looking" manner while the inflation responsiveness is weak enough to be pro-cyclical to inflation pressure and the rule is also responsive to exchange rate. They speculate that the forward-looking rule would reflect the progress in inflation targeting framework, i.e., the adoption of the Forecasting and Policy Analysis System (FPAS) in Mongolia, which aims at forecast-based policy formation and decision making, and effective communication with the public under the inflation targeting framework.

The combined evidences between the inflation targeting with the forward-looking rule and the loss of pass-through effect from exchange rate to consumer prices are consistent with Gagnon and Ihrig (2004) as well as Taguchi and Sohn (2014), since the macro model of Gagnon and Ihrig (2004) presumes the forward-looking type of monetary policy rules for monetary authorities' behavior. To sum up, the forward-looking inflation targeting could lead to the loss of the pass-through effect, since it effectively works on the expectations of domestic agents such that they are less inclined to change prices in response to a given exchange rate shock under the strong commitment of the monetary authority toward price stability.

\section{Concluding Remarks}

This paper aimed to provide empirical evidence on the relationship between inflation targeting and the pass-through effect from exchange rate to consumer prices, focusing on the case of Mongolia. The study estimated a VAR model, and examined the impulse responses of consumer prices to the shock of exchange rate for the pre-inflation targeting period and the post-inflation targeting period. This study contributed to enriching the evidence, since there have been no studies that deal with the pass-through explicitly in relation with inflation targeting in Mongolia. The VAR analysis identified the existence of the pass-through effect during the pre-inflation targeting period and the loss of the pass-through during the post-inflation targeting period. As Taguchi and Sohn (2014) argues, the difference on whether the pass-through declines or remains unchanged under inflation targeting framework would come from the modality of inflation targeting: the loss of pass-through requires the inflation targeting accompanied with an inflation-responsive rule in a "forward-looking" manner. Taguchi and Khishigjargal (2018) finds that the Mongolian current monetary policy rule under inflation targeting is characterized as inflation-responsive rule with "forward-looking" form. It is, therefore, speculated that the loss of pass-through comes from the "forward-looking" monetary policy rule under the Mongolian inflation targeting framework, and the combined evidences between the forward-looking rule in inflation targeting and the loss of pass-through are consistent with the arguments of Taguchi and Sohn (2014) and Gagnon and Ihrig (2004). Although the pass-through itself becomes less serious under the inflation targeting in Mongolia, however, the high dependency on imports still makes Mongolian economy fragile and vulnerable to exchange rate fluctuation. Thus the policy recommendation for strengthening domestic industries is still valid in the current Mongolian 
economy.

\section{References}

Bhargava, A. (1986). On the theory of testing for unit roots in observed time series. Review of Economic Studies, 53, 369-384. http://dx.doi.org/10.2307/2297634

Buyandelger, O. E. (2015). Exchange rate pass-through effect and monetary policy in Mongolia: Small open economy DSGE model. Procedia Economics and Finance, 26, 1185-1192. http://dx.doi.org/10.1016/S2212-5671(15)00950-8

Coulibaly, D., \& Kempf, H. (2010). Does Inflation Targeting Decrease Exchange Rate Psaa-Through in Emerging Countries?. Banque de France Working Paper. No. 303.

Daboussi, O. M., \& Thameur, N. (2014). Inflation Targeting and Exchange Rate Pass-Through: A Comparative Study in Emerging Markets. International Journal of Innovation and Applied Studies, 9(1), 317-324.

Dilla, S., Achsani, N. A., \& Anggraeni, L. (2017). Do Inflation Targeting Really Reduced Exchange Rate Pass-through? International Journal of Economics and Financial Issues, 7(3), 444-452.

Dornbusch, R. (1987). Exchange Rates and Prices. American Economic Review, 77. 93-106.

Dube, S. (2016). Exchange Rate Pass-Through (ERPT) and Inflation-Targeting (IT): Evidence from South Africa. International Economics, 69(2), 121-150.

Edwards, S. (2006). The relationship between exchange rates and inflation targeting revisited. NBER (National Bureau of Economic Research) Working Paper Series. No. 12163.

Eichengreen, B. (2002). Can emerging markets float? Should they inflation target? Working Paper (Banco Central do Brazil). No. 36. http://dx.doi.org/10.4337/9781847200259.00020

Gagnon, J. E., \& Ihrig, J. (2004). Monetary policy and exchange rate pass-through. International Journal of Finance and Economics, 9(4), 315-338.

http://dx.doi.org/10.1002/ijfe.253

Guillermo, S., \& Brindis, M. R. (2014). Analyzing the Exchange Rate Pass-through in Mexico: Evidence Post Inflation Targeting Implementation. Ensayos Sobre Politica Economica, 32(74), 18-35. http://dx.doi.org/10.1016/S0120-4483(14)70025-9

Guo, Z. Y. (2017). Order Flow and Exchange Rate Dynamics in Continuous Time: New Evidence from Martingale Regression. International Journal of Economics and Financial Issues, 7(2), 507-512. http://dx.doi.org/10.2139/ssrn.3013781

Johansen, S. (1995). Likelihood-based Inference in Cointegrated Vector Autoregressive Models. Oxford: Oxford University Press. http://dx.doi.org/10.1093/0198774508.001.0001

Karahan, O. (2017). Exchange Rate Pass-Through in Turkey Before and After the Adoption of Inflation Targeting Regime. Financial Asset and Investing, 8(2), 37-48.

http://dx.doi.org/10.5817/FAI2017-2-3 
Kuncoro, H. (2015). Inflation Targeting, Exchange Rate Pass-through, and Monetary Policy Rule in Indonesia. International Journal of Business, Economics and Law, 7(3), 14-25.

Lee, J. (1997). The Response of Exchange Rate Pass-Through to Market Concentration in a Small Economy: The Evidence from Korea. Review of Economics and Statistics, 79(1), 142-145. http://dx.doi.org/10.1162/003465397556485

Mishkin, F. S. (2000). Inflation targeting in emerging market countries. American Economic Review, 90(2), 105-109. http://dx.doi.org/10.1257/aer.90.2.105

Mishkin, F.S. Posen, A.S. (1998). Inflation targeting: lessons from four countries. NBER (National Bureau of Economic Research) Working Paper Series. No. 6126.

Mishkin, F. S., \& Schmidt-Hebbel, K. (2007). Does inflation targeting make a difference? NBER (National Bureau of Economic Research) Working Paper Series. No. 12876.

Ng, S., \& Perron, P. (2001). Lag length selection and the construction of unit root tests with good size and power. Econometrica, 69, 1519-1554.

http://dx.doi.org/10.1111/1468-0262.00256

Nogueira, R. P. (2007). Inflation Targeting and Exchange Rate Pass-through. Economia Aplicada, 11(2), 189-208. http://dx.doi.org/10.1590/S1413-80502007000200002

Odria, L. R. M., Castillo, P., \& Rodriguez, G. (2012). Does the exchange rate pass-through into prices change when inflation targeting is adopted? The Peruvian case study between 1994 and 2007. Journal of Macroeconomics, 34(4), 1154-1166.

Oladipo, O. (2017). The Effects of Inflation Targeting on Exchange Rate Pass-Through to Domestic Prices: A Case Study of South Africa. Advances in Management and Applied Economics, 7(6), 1-4.

Phillips, P., \& Perron, P. (1988). Testing for unit root in time series regression. Biometrika, 74, 335-346. http://dx.doi.org/10.1093/biomet/75.2.335

Siregar, R., \& Goo, S. (2008). Inflation Targeting Policy: The Experiences of Indonesia and Thailand. CAMA (Centre for Applied Macroeconomic Analysis in the Australian National University) Working Paper. No. 23.

Taylor, J. B. (2000). Low inflation, pass-through, and the pricing power of firm. European Economic Review, 44, 1389-1408. http://dx.doi.org/10.1016/S0014-2921(00)00037-4

Taguchi, H., \& Khishigjargal, E. (2018). Monetary Policy Rule under Inflation Targeting in Mongolia. East Asian Economic Review, 22(4), 531-555.

http://dx.doi.org/10.11644/KIEP.EAER.2018.22.4.353

Taguchi, H., \& Sohn, W. K. (2014). Inflation Targeting and the Pass-through Rate in East Asian Economies. Asian Economic Journal, 28(2), 139-159.

http://dx.doi.org/10.1111/asej.12029

Zorzi, Z. Hahn, E. Sanchez, M. (2007). Exchange-rate pass through in Emerging Countries. 
European Central Bank Working paper. No. 739.

\section{Copyright Disclaimer}

Copyright for this article is retained by the author(s), with first publication rights granted to the journal.

This is an open-access article distributed under the terms and conditions of the Creative Commons Attribution license (http://creativecommons.org/licenses/by/3.0/). 